\title{
Correction to: Development of two quantitative PCR assays \\ for detection of several Cottus species from environmental DNA in Pacifc coast watersheds of North America
}

\author{
Marshal S. Hoy ${ }^{1}\left(\mathbb{0} \cdot\right.$ Carl O. Ostberg $^{1}$
}

Published online: 21 November 2019

(c) This is a U.S. government work and its text is not subject to copyright protection in the United States; however, its text may be subject to foreign copyright protection 2019

\section{Correction to: Conservation Genetics Resources}

https://doi.org/10.1007/s12686-019-01118-7

In the original publication of the article, the latitude and longitude values of the eDNA sample site, "Thornton Creek, WA" were published incorrectly in Table 2.

The corrected Table 2 is given below.

Publisher's Note Springer Nature remains neutral with regard to jurisdictional claims in published maps and institutional affiliations.

The original article can be found online at https://doi.org/10.1007/ s12686-019-01118-7.

Marshal S. Hoy

mhoy@usgs.gov

1 Western Fisheries Research Center, USGS, Seattle, WA, USA 
Table 2 Locations and river kilometers (rkm) of field collected water samples for assay validation and the number of positive qPCR results (out of 6 qPCRs performed)

eDNA sample site

Collection date Latitude Longitude

$\begin{array}{lll}\begin{array}{l}\text { Sculp- } \\ \text { COI_17-86 }\end{array} & \text { Sculp- } & \text { Cottus species present } \\ \text { amplifications } & \text { COI_129-226 } & \\ \text { amplifications } & \end{array}$

Lower Elwha River (0.3 rkm) 9/23/2016

Lower Elwha River (5 rkm) 9/23/2016

$\begin{array}{lll}48.1442 \mathrm{~N} & 123.5621 \mathrm{~W} & 6 \\ 48.1137 \mathrm{~N} & 123.5537 \mathrm{~W} & 5 \\ 48.0685 \mathrm{~N} & 123.5786 \mathrm{~W} & 6 \\ 47.7590 \mathrm{~N} & 123.4637 \mathrm{~W} & 0 \\ 47.7590 \mathrm{~N} & 123.4652 \mathrm{~W} & \\ 47.7589 \mathrm{~N} & 123.4637 \mathrm{~W} & \\ 47.6948 \mathrm{~N} & -122.2728 \mathrm{~W} & 6\end{array}$

6

C. rhotheus and C. perplexux

9/23/2016

Lower Elwha River (8 rkm)

$9 / 23 / 2016$

Upper Elwha River

$9 / 21 / 2016$

Thornton Creek, WA

$4 / 11 / 2018$

$47.6948 \mathrm{~N}-122.2728 \mathrm{~W} 6$

C. rhotheus and C. perplexux

C. rhotheus and C. perplexux

None

$\begin{array}{ll}6 & \text { None } \\ 0 & \end{array}$

(

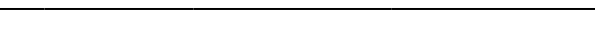

